\title{
Bağımsız Denetim Kapsamında İşletme Sürekliliği: Borsa İstanbul'da İmalat Sektöründe Faaliyet Gösteren İşletmeler Üzerine Bir Araştırma
}

\section{Business Continuity in the Scope of Independent Audit: A Research on Manufacturing Companies Operating in Borsa Istanbul}

\author{
Doç. Dr. Serpil Senal ${ }^{1}$ - Ahmet Erkan ${ }^{2}$
}

Başvuru Tarihi: 14.02.2019

Kabul Tarihi: 23.12.2019

\section{Öz}

Son yıllarda yaşanan işletme iflası ile birlikte hem ülke ekonomisinin, hem de yatırımcıların ciddi zarar görmesi, işletmelerin sürekliliği ile ilgili düzenlemeleri de beraberinde gelmiştir. Söz konusu konuya hem Türkiye Muhasebe ve Finansal Raporlama Standartları'nda, hem de Bă̆ımsız Denetim Standartlari'nda yer verilmiştir. Buna göre, işletme yönetimi finansal raporları süreklilik varsayımı altında hazırlamak ile sorumlu iken, bağımsız denetçi de finansal tabloların süreklilik esasında hazırlanıp hazırlanmadiğı yönünde bir görüş oluşturmakla sorumlu tutulmuştur. Çünkü işletmelerin beklenmedik iflasları yatırımcının bağımsız denetim raporlarına olan güvenini de zedelemektedir. Bu doğrultuda çalışmada öncelikle Borsa İstanbul'da imalat sanayisinde işlem gören işletmelerin 2009-2017 yıllarında yayınladıkları finansal tabloların süreklilik ile ilgili bir belirsizlik taşıyıp taşımadıkları tahmin edilmeye çalışılmıştır. Bu değerlendirme için Altman Z Skoru modelinden faydalanılmıştır. Daha sonra çalışmada tahmin sonuçları ile bu finansal tablolar için verilen denetçi görüşleri arasındaki ilişki incelenmiştir. Çalışmanın sonucunda eğer model süreklilik ile ilgili bir belirsizlik tahmininde bulunduysa denetçinin de raporunda bu duruma yer verdiği ve genellikle şartlı görüş ya da olumlu görüş bildirerek açıklama parağrafi eklediği tespit edilmiştir.

Anahtar Kelimeler: Bağımsız Denetim, Denetçi Görüşü, Süreklilik

\footnotetext{
1 Süleyman Demirel Üniversitesi İktisadi İdari Bilimler Fakültesi Bankacılık ve Finans Böülümü, serpilsenal@sdu.edu.tr, ORCID: 0000-0002$8681-7526$

2 Süleyman Demirel Üniversitesi İktisadi İdari Bilimler Fakültesi, aerkan15@hotmail.com, ORCID: 0000-0002 74407933
} 


\begin{abstract}
Along with the bankruptcy of the enterprises in recent years, both the national economy and the serious damage of the investors have been related to the continuity of the enterprises. Such issues both in Turkey Accounting and Financial Reporting Standards, are included in both Auditing Standards. Accordingly, the entity management is responsible for preparing the financial reports under the assumption of continuity and the independent auditor is responsible for establishing an opinion as to whether the financial statements are prepared on a continuous basis. Because unexpected bankruptcies of enterprises have undermined investor's confidence in independent audit reports. Accordingly, the financial statements published by Borsa Istanbul in 2009-2017, which are The Manufacturing Industry in Borsa Istanbul, are evaluated in terms of continuity assumption. The Altman $Z$ Score model was used for this evaluation. Then, the relationship between the mentioned results and the auditor opinions given for these financial reports was examined. As a result of the study, if the model predicted an uncertainty about the continuity, it was found that the auditor included this situation in his report and generally provided conditional opinion or affixed the explanation paragraph with positive opinion.
\end{abstract}

Keywords: Independent Audit, Auditor's Opinion, Continuity

\title{
Giriş
}

Son yıllarda ekonominin durgun olduğu dönemlerde işletmelerin beklenmedik iflasları ile birlikte yatırımcılar, bağımsız denetçiler tarafından hazırlanan denetim raporlarının güvenilir olup olmadıklarını eleştirmeye başlamışlardır. Piyasalar, WorldCom ve Enron gibi vakalarla birlikte ciddi hasar almış ve artık bu türden olaylarla karşılaşmamak için yeni tedbirler alınması gündeme gelmiştir. Çünkü işletmeler çoğu zaman yaptıkları hileleri gizlemek amacıyla finansal pozisyonları ve faaliyetleri ile ilgili yanlış beyanlarda bulunabilmektedir. Bu nedenle denetçi görüşü yatırımcılar için büyük önem arz etmektedir (Stanisic vd., 2013, s.423).

Yaşanan finansal krizlerin temeline bakıldığında, krizlerin büyük bir kısmının işletmelerin finansal raporlarında, bağımsız denetçilerin ise, denetim raporlarında işletmenin sürekliliği ile ilgili belirsizliğe yeterince ve doğru şekilde yer vermemesinden kaynaklandığı görülmektedir (Attila vd., 2012:451). Çünkü işletmelerin finansal raporları ve denetçilerin hazırladıkları denetim raporları birçok hususta olduğu gibi, işletmelerin sürekliliği ile ilgili karar verme sürecinde de finansal tablo kullanıcıları için önemli bir yardımcıdır.

Süreklilik kavramına yatırımcı açısından bakıldığında, işletmenin uzun vadede faaliyetlerini devam ettirebilecek yeteneğe sahip olduğunun göstergesidir (Triani, 2017, s.31). Süreklilik kavramı aslında finansal tabloların hazırlanmasında temel varsayımdır. Kavramsal Çerçeve'de, finansal tabloların normal olarak işletmenin devamlılı̆̆1 ve öngörülebilir bir gelecekte de faaliyetlerini sürdüreceği varsayımına dayanılarak hazırlanması gerektiği belirtilmiştir. Böylece, işletmenin tasfiye niyetinin ve ihtiyacının olmadığı, faaliyet hacminin önemli bir düzeyde 
azalmayacağı varsayılır. İşletmede böyle bir durum söz konusu ise finansal raporlar farklı bir şekilde hazırlanır ve bu gerekçe mutlaka açıklanmalıdır (Kavramsal Çerçeve, Bölüm 4, m.4.1). Finansal Raporlama Konseyi (FRC) bu hususta işletme yönetiminin sorumluluğunu ve değerlendirmesi gereken konuları belirtmiştir. Buna göre (Uzay,2017, s.164):

- Yönetim işletmenin sürekliliğini devam ettirebilme yeteneğini değerlendirmeli,

- Yönetim, işletmenin sürekliliğini devam ettirebilme yeteneği hakkında önemli şüphelere neden olan olay ya da koşulları açıkça belirtmelidir.

Türkiye Muhasebe Standardı (TMS) 1 Finansal Tabloların Sunuluşu Standardı'na göre; yönetim, finansal tabloları düzenlerken işletmenin faaliyetlerini süreklilik içerisinde devam etme yetisini değerlendirir. Yönetimin şirketi tasfiye etme veya ticari faaliyetini sona erdirme niyeti veya mecburiyeti yoksa finansal tablolar süreklilik kavramına göre düzenlenir. Yönetim, değerlendirmelerini yaparken işletme faaliyetlerinin sürekliliğine kuşku düşürecek önemli belirsizlikler taşıyan olaylar veya koşulların farkındaysa, bu belirsizlikleri açıklar. İşletme, finansal tablolarını süreklilik esasına göre hazırlamaması halinde, bu hususu, finansal tablolarını düzenlemesi sırasında dayandırdığı temel ve işletmenin süreklilik arz etmeyecek şekilde değerlendirilmesinin nedeni ile birlikte açıklar (TMS 1, p.25).

İşletmenin sürekliliği varsayımının geçerli olup olmadığının değerlendirilmesinde, yönetim (bununla sınırlı olmamak kaydıyla) raporlama döneminin sonundan itibaren en az on iki aylık dönemi kapsayacak şekilde gelecek hakkında elde edilebilen bütün bilgileri dikkate alır. İşletmenin geçmişte kârlı faaliyetler yürütmesi ve finansal kaynaklara kolay ulaşması durumunda işletme ayrıntılı analizler yapmadan süreklilik esasının geçerli olduğu sonucuna ulaşabilir. Diğer durumlarda yönetimin, işletmenin sürekliliği esasının geçerli olduğuna karar vermeden önce, mevcut ve beklenen karlılık, borç ödeme planları ve yenilenecek finansmanlara ilişkin potansiyel kaynaklarla ilgili pek çok faktörü dikkate alması gerekebilir (TMS 1, p. 26).

Bağımsız denetim kapsamında bakıldığında ise süreklilik, denetçinin gelecekte işletmenin faaliyetlerini sürdürebilecek yeteneğe sahip olduğuna dair inancı olup olmadığının bir göstergesidir (Triani, 2017, s.31). Bağımsız denetçi mali tabloların doğruyu göstermesi konusunda bir garantör olmamakla birlikte, denetim raporunda gerekli açıklamayı yaparak, mali tablo kullanıcılarını bu hususta aydınlatmakla sorumludur (Selimoğlu vd, 2008: 65). İşletmenin sürekliliğinin kritik bir öneme sahip olması nedeniyle bağımsız denetçiye de büyük ölçüde bu konuda sorumluluklar verilmiştir. Özellikle Bağımsız Denetim Standardı 570 İşletmenin Sürekliliği Standardı'na göre denetçinin bu kapsamdaki sorumlulukları aşağıda yer almaktadır (BDS 570, p. 6):

- Finansal tabloların hazırlanmasında yönetimin işletmenin sürekliliği esasını kullanmasının uygunluğu hakkında yeterli ve uygun denetim kanıtı elde etmek ve yönetimin bu esası kullanmasının uygunluğuna ilişkin bir sonuca varmak, 
- Elde edilen denetim kanıtlarına dayanarak işletmenin sürekliliğini devam ettirme kabiliyetine ilişkin önemli bir belirsizliğin mevcut olup olmadığı konusunda bir sonuca varmak.

Standarda göre, işletmenin sürekliliği ile ilgili durumu, denetçinin görüşünü de etkilemektedir. Şekil 1'de süreklilik varsayımı ile denetçi görüşü arasındaki ilişkiye yer verilmiştir.

İşletme yönetimi finansal tabloları süreklilik varsayımına göre mi hazırlamış?

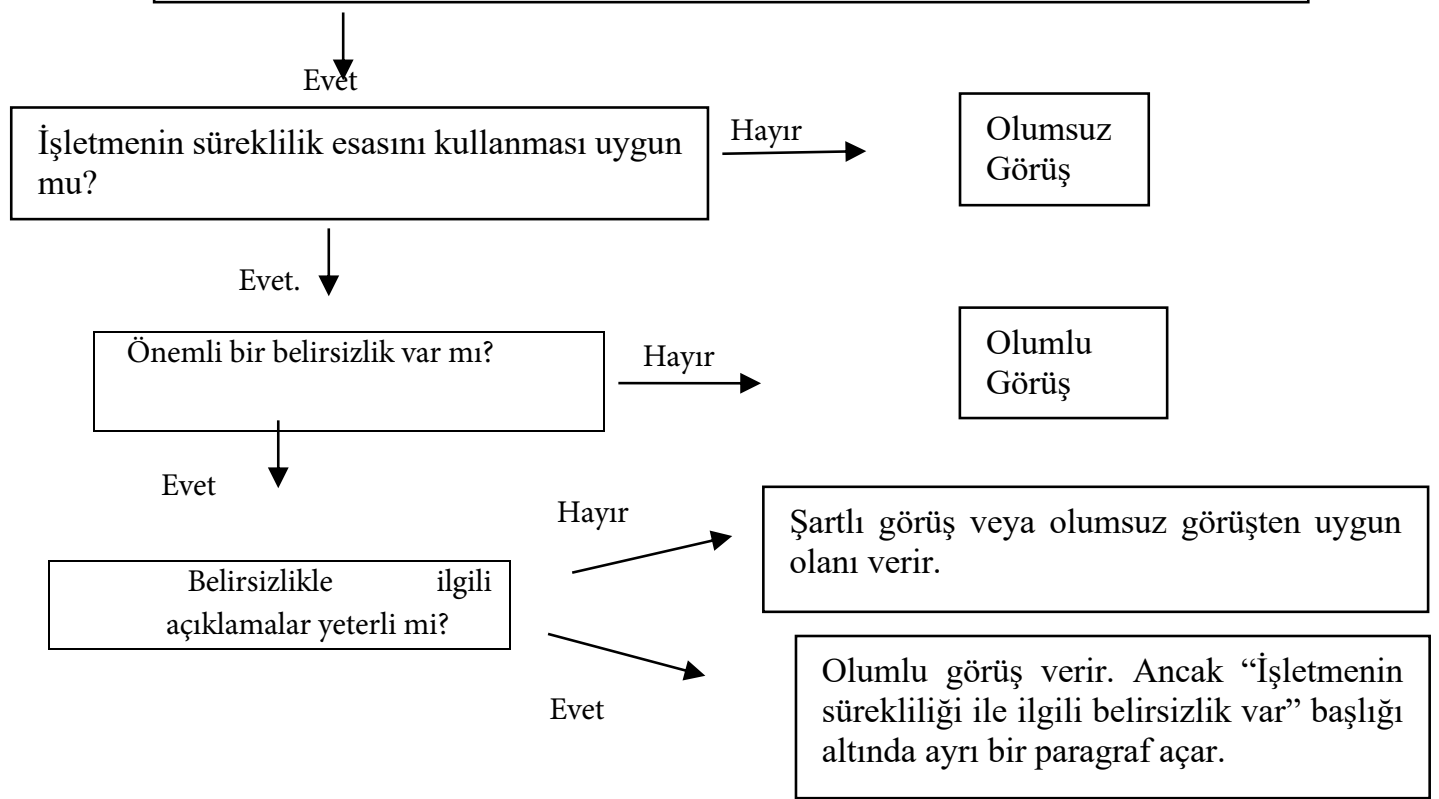

Kaynak: (Provasi vd., 2015,s.29)

\section{Şekil 1. Süreklilik Varsayımı İle İlgili Denetçi Görüşü}

Şekil 1'de görüldüğü üzere, finansal tabloların işletmenin sürekliliği esasına göre hazırlanmış olması, ancak yönetimin "işletmenin sürekliliği varsayımını" kullanmasının denetçinin yargısına göre uygun olmaması ve söz konusu durum ile ilgili yeterli açıklamanın bulunmaması durumunda denetçi şartlı görüş veya olumsuz görüşten uygun olanını vermektedir (BDS 570, p. 21). Bununla birlikte bir bütün olarak finansal tablolara ilişkin birden çok önemli belirsizliğin mevcut olduğu durumlarda görüş vermekten kaçınmayı da uygun görebilir ((BDS 570, p.A3234). Finansal tablolardaki önemli belirsizliğe ilişkin yeterli açıklamanın yapılması durumunda denetçi, olumlu görüş verir ancak "İşletmenin sürekliliğiyle ilgili önemli belirsizlik var" başlı̆̆ altında ayrı bir bölüm açmalıdır (BDS 570, p.22).

Denetçi tarafindan talep edilmesine rağmen yönetimin değerlendirme yapma veya değerlendirmeyi genişletme konusunda istekli olmaması durumunda denetçi, bu durumun denetçi raporu için etkilerini mütalaa eder (BDS 570, p. 24). 
Bağımsız Denetim Standardı (BDS) 570, işletmelerin süreklilik göstergelerini; işletme faaliyetleri ile ilgili göstergeler, finansal göstergeler ve diğer konularla ilgili olmak üzere üç kategoriye ayırmıștır. Standart bu göstergelerin tek başına var olmasının her zaman işletmenin sürekliliği ile ilgili önemli bir belirsizliğin var olduğu anlamına gelmeyeceğini de belirtmiştir. Finansal durumla ilgili olay ve şartlar standartta şu şekilde sıralanmaktadır (BDS 570,p.A3-A4):

- Net yükümlülük veya kısa vadeli net yükümlülük pozisyonu,

- Sabit vadeli borçların vadelerinde geri ödeneceğine veya yenileneceğine dair gerçekçi olmayan beklentiler veya uzun vadeli varlıkları finanse etmek için kısa vadeli borçlara gereğinden fazla bağlı olması,

- Kredi verenler tarafından sağlanan finansal desteğin geri çekileceğine dair belirtiler,

- Tarihi veya ileriye dönük finansal tablolarda gösterilen, işletme faaliyetleriyle ilgili negatif nakit akışları,

- Temel finansal oranlardaki olumsuzluklar,

- Önemli tutarlardaki faaliyet zararı veya nakit akışı yaratan varlıkların değerindeki önemli azalışlar,

- Temettü ödemelerindeki gecikme veya kesilmeler,

- Alacaklılara vade tarihinde ödeme yapılamaması,

- Kredi sözleşmelerinin şartlarına uyulamaması,

- Yeni ürün geliştirilmesi veya diğer önemli yatırımlar için finansman temin edilememesi,

- İşletme faaliyetleriyle ilgili şartlar (BDS 570,p.A3-A4):

- Yönetimin işletmeyi tasfiye etme veya faaliyetleri durdurma niyeti,

- Kilit yönetim kadrosunun boşalarak yerlerinin doldurulmaması,

- Önemli bir pazarın, kilit müşteri veya müşterilerin, imtiyaz, lisans veya ana tedarikçi veya tedarikçilerin kaybedilmesi,

- İşgücüyle ilgili yaşanan sıkıntılar,

- Önemli hammadde darboğazı,

- Oldukça başarılı bir rakibin ortaya çıkması,

- Diğer konularla ilgili şartlar (BDS 570,p.A3-A4): :

- Finansal kuruluşların borç ödeme gücü veya likidite yükümlülükleri gibi sermaye yeterlilik yükümlülüklerine veya diğer yasal yükümlülüklere aykırılık,

- İşletme aleyhine açılmış, sonuçlanmamış ve işletmenin aleyhine sonuçlanması durumunda işletmenin karşılamayacağ taleplere sebep olabilecek davalar,

- İşletmeyi olumsuz yönde etkilemesi beklenen mevzuat değişiklikleri veya hükümet politikalarındaki değişiklikler,

- Oluştuğunda sigorta kapsamında bulunmayan veya eksik sigortalanmış felaketler,

\section{Araştırmanın Amacı ve Kapsamı}

Çalışmanın daha önceki bölümlerinde de bahsedildiği üzere, işletmenin sürekliliği ile ilgili belirsizliğe hem finansal raporlarda hem de denetim raporlarında düzenlemelerin gerekli gördüğü şekilde yer verilmemesi yatırımcı kararlarını ve dolayısı ile ülke ekonomisini olumsuz 
etkilemektedir. Bu nedenle çalışmada öncelikle finansal tablo verileri kullanılarak işletmelerin sürekliliği ile ilgili belirsizliğe sahip olup olmadıkları model yardımı ile tahmin edilmiştir. Bunun için uygulamada sıklıkla iflas tahminlerinde kullanılan Altman Z Skoru modelinden faydalanılmıştır. Çalışmanın bundan sonraki bölümünde tahmin sonuçları ile bu finansal raporlar için hazırlanan denetim raporları arasındaki ilişkiye bakılmıştır. Böylece modelin süreklilik ile ilgili belirsizlik tahmini yaptığı finansal raporlar için hazırlanan denetim raporlarında da bu belirsizliğe yer verilip verilmediğinin ortaya konulması hedeflenmektedir. Yer verilmesi durumunda hangi denetim görüşünü tercih ettiklerinin belirlenmesi amaçlanmaktadır.

Araştırmada Borsa İstanbul'da işlem gören ve imalat sektöründe yer alan işletmelerin, Türkiye Finansal Raporlama Standartları ve Muhasebe Standartları'nın finansal tablolar üzerindeki etkisi de dikkate alınarak, karşılaştırılabilirliği artırmak amacıyla 2009-2017 yıllarına ait finansal tabloları çalışma kapsamına dahil edilmiştir. Buna göre, Borsa İstanbul'da imalat sektöründe işlem gören işletme sayısı 179'dur. Ancak denetçi görüş çeşitliliğinin en fazla olduğu iki alt sektör olan "Gıda, içki, tütün” ve dokuma, giyim eşyası ve deri” sektörlerinde yer alan 52 işletmeden 39 işletmenin 2009-2017 yıllarına ait finansal tabloları çalışmada kullanılmıştır. Verilerinin süreklilik göstermemesi nedeniyle 13 işletme, çalışma kapsamı dışında tutulmuştur. Çalışma kapsamına alınan 39 işletmenin 18 tanesi dokuma, 21 tanesi içki tütün sektöründendir. Bu doğrultuda çalışmada 2009-2017 yıllarına ait toplamda 351 finansal tablo ve bu tablolar için hazırlanan 351 denetim raporu incelenmiştir.

\section{Literatür Araştırması}

Yapılan çalışmalarda işletmelerin sürekliliği ile ilgili belirsizliğin tahmini için birçok modelden faydalanıldığı görülmektedir. Çalışmaların birçoğunda modeller işletmelerin iflas riskini değerlendirmek amacıyla kullanılmıştır. Bununla birlikte bazı çalışmalarda ise, modeller yardımı ile işletmenin sürekliliği değerlendirilmiş ve bağımsız denetçinin görüş oluşturmasına kolaylık sağlanması amaçlanmıştır.

Yıldız (2017) çalışmasında; bağımsız denetçi tarafından işletmenin sürekliliği konusunda belirsizlik bulunduğu ifade edilen işletmelerin mali tablolarını incelemiştir. Buna göre 20062014 yılları arasında işletmelerin her yıl için bilanço, gelir tablosu ve nakit akım tablolarında yer alan ana kalemler ayıklanmış ve bu verilerin yıllar itibari ile gösterdiği eğilimler ortaya konulmuştur.

Terzi vd. (2016) çalışmalarında; denetim açısından işletmenin sürekliliğinin ölçülmesinde güvenilir bir model oluşturmayı amaçlamışlardır. Model için finansal tablo oranlarından faydalanılmış ve genetik algoritma kullanılmıştır. 
Yılmaz ve Yaşar (2018) çalışmalarında; işletmenin sürekliliğinin değerlendirilmesinde kullanılacak göstergelerin neler olabileceğini araştırmışlardır. Çalışmada içerik analizi yapılmıştır.

Tanç (2010) doktora tez çalışmasında; denetçilerin işletmenin sürekliliğine ilişkin görüş oluşturulmasında istatistiksel örnek model ve değerlendirme kriterlerinin oluşturulmasını amaçlamıştır. Çalışmada 16 değişkenle birlikte yapay sinir ağı ve sıralı lojistik regresyon analizi kullanılmıştır.

Turaboğlu v.d., (2017) çalışmasında işletmelerin finansal başarısızlıkları ile sermaye yapıları arasındaki ilişkiyi incelemiştir. Çalışmada işletme başarısızlığının değerlendirilmesi amacıyla Altman Z Skoru ve Springate S Skoru kullanılmıştır.

Kulalı (2016) çalışmasında; Altman Z Skoru testi ile işletmelerin iflas riskini tahmin etmeye çalışmıştır. Çalışmada iflas eden işletmelerin finansal oranları kullanılmış ve modelin iflas riski olan işletmelerle ilgili gerçeğe yakın tahminlerde bulunduğu tespit edilmiştir.

Yukarıda da görüldüğü üzere, çalışmalarda genellikle görüş oluşturmasında denetçiye yardımcı olması amacıyla işletmenin sürekliliği ile ilgili belirsizliği tahmin edecek olan en iyi modelin tespiti araştırılmıştır. Bu çalışmada ise literatürde doğru tahminler yaptığı kabul edilmiş bir model yardımıyla işletmelerin sürekliliği ile ilgili belirsizlik tahmin edilerek, denetçilerin bu duruma raporlarında yer verip vermedikleri, yer vermeleri durumunda hangi denetim görüşünü tercih ettikleri incelenmiştir.

\section{Araştırmanın Metodolojisi ve Araştırmanın Hipotezleri}

Finansal oranlar işletmelerin finansal performanslarını değerlendirmek için önemli bir araçtır. Bununla birlikte finansal oranlar işletmelerin sürekliliği ile ilgili belisizliğin tahmininde de kullanılmaktadır. 1968 yılında Edward Altman işletmelerin finansal performanslarını ve sürekliliği ile ilgili belirsizliği tahmin edecek bir formül geliştirmiştir. Söz konusu formülde 5 finansal oran kullanmıştır. Oluşturulan formüller 33 iflas etmiş, 33 tane de iflas riski taşımayan firma üzerinde uygulanmış ve tahmin oranının yüksek olduğu görülmüştür. Söz konusu oranlar aşağıdaki gibidir (Altman, 1968:592):

(X1) Net Çalışma Sermayesi / Toplam Varlıklar

(X2) Dağıtılmamış Karlar / Toplam Varlıklar

(X3) Faiz ve Vergi Öncesi Kar / Toplam Varlıklar

(X4) Piyasa Değeri / Toplam Borçlar

(X5) Net Satışlar / Toplam Varlıklar

Farklı ağırlıklara sahip bu beş finansal oran yardımıyla oluşturulan formülasyon ise aşağıda belirtilmiştir:

Zscore $=0.012^{\star} \mathrm{X} 1+0.014^{\star} \mathrm{X} 2+0,033^{\star} \mathrm{X} 3+0,006^{\star} \mathrm{X} 4+0,999^{\star} \mathrm{X} 5$ 
Yukarıdaki eşitlik kurularak hesaplanan Z-Skorunun, 1.8 veya daha küçük bir değere sahip olması işletmenin sürekliliği ile ilgili belirsizliğin olduğu yönünde bir tahmini ifade ederken, skorun $1,8^{\prime}$ in üstünde olması işletmelerin süreklilikleri ile ilgili belirsizlik tahmini olmadığ yönünde yorumlanmaktadır.

Çalışmada öncelikle işletmelerin süreklilikleri Altman Z skoru modeli yardımıyla tahmin edildikten sonra söz konusu modellerin tahmin sonuçları ile o dönemde hazırlanan denetim raporlarında belirtilen denetçi görüşleri arasındaki ilişkinin değerlendirilmesi için SPSS 15.0 yardımı ile verilere Ki-Kare bağımsızlık testi uygulanmıştır. Ki kare bağımsızlık testi, iki ya da daha fazla değişken grubu arasında ilişki bulunup bulunmadığını incelemek için kullanılan parametrik olmayan bir testtir (Kalayc1, 2005: 94). Bu testte ilişki kurulan değişkenlerin her ikisi de nominal (Sınıflama) ya da ordinal (Sıralama) ölçeklidir. Parametrik testlerin kullanılabilmesi için veri setinin 30 'dan büyük olması ve verilerin hem homojen olması hem de normal dağılım göstermesi gerekmektedir. Çalışma kapsamında kullanılan verilerin normal dağılım ve homojenlik göstermemesi nedeniyle parametrik olmayan testlerden Ki kare testi tercih edilmiştir (Eymen, 2007, s.148).

Araştırma ile ilgili kurulan hipotezler alternatif hipotezler olup sonucu kabul veya red olan hipotezlerdir. Çalışma kapsamında araştırılan hipotezler:

H0: Denetçi görüşü ile Altman Z skoru süreklilik tahmin sonuçları arasında ilişki yoktur.

H1: Denetçi görüşü ile Altman Z skoru süreklilik tahmin sonuçları arasında ilişki vardır.

\section{Araştırmanın Bulguları}

Çalışmada öncelikle Altman Z Skoru modeli yardımı ile işletmelerin 2009-2017 yılları arasında süreklilikleri ilgili bir belirsizlik olup olmadığı tahmin edilmeye çalışılmıştır. Buna göre 20092017 yılları arasında yayınlanan 155 finansal raporda süreklilik ile ilgili belirsizlik tahmin edilirken, 196 finansal raporda belirsizlik olduğu yönünde bir sonuca ulaşılmamıştır. Araştırmanın bundan sonraki aşamasında söz konusu finansal raporlar için hazırlanmış olan denetim raporları incelenmiş ve bu finansal raporlar için hangi denetim görüşünün verildiği tespit edilmiştir. Ki kare bağımsızlık testi yardımı ile modelin tahmin sonuçları ile denetçi görüşleri arasındaki ilişki değerlendirilmiştir.

Tablo 1. Ki kare Bă̆ımsızlık Test Sonuçları

\begin{tabular}{|l|l|l|l|}
\hline & Değer & Serbestlik derecesi & Anlamlılık değeri (p) \\
\hline Pearson Ki Kare & 55,582 & 3 &, 000 \\
\hline a 2 cells $(25,0 \%)$ have expected count less than 5. The minimum expected count is 1.42 \\
\hline
\end{tabular}


Tablo 1'de görüldügü üzere, Anlamlılık değeri 0,05 değerinden büyük olduğu için Ho hipotezi reddedilerek H1 hipotezi kabul edilmiştir. Buna göre işletmelerin süreklilikleri ile ilgili tahmin sonuçları ile denetçi görüşleri ile arasında anlamlı bir ilişki olduğu görülmektedir. Bundan sonraki bölümde söz konusu ilişki incelenmiştir.

Tablo 2. Ki Kare Karşılaştırma Tablosu

\begin{tabular}{|c|c|c|c|c|}
\hline \multicolumn{2}{|l|}{$\begin{array}{l}\text { Model Tahmini } \\
\text { Denetçi Görüşü }\end{array}$} & \multirow{2}{*}{$\begin{array}{l}\text { Süreklilik Ile ilgili } \\
\text { belirsizlik var }\end{array}$} & \multirow{2}{*}{$\begin{array}{l}\text { Süreklilik İle ilgili } \\
\text { belirsizlik yok } \\
\\
24\end{array}$} & \multirow{2}{*}{$\begin{array}{l}\text { Toplam } \\
\\
54 \\
\end{array}$} \\
\hline & Frekans & & & \\
\hline Şartl1 Görüş & Yüzde & $\% 56$ & $\% 44$ & $\% 100$ \\
\hline \multirow[t]{2}{*}{ Olumlu Görüş } & Frekans & 87 & 171 & 258 \\
\hline & Yüzde & $\% 34$ & $\% 66$ & $\% 100$ \\
\hline \multirow{2}{*}{$\begin{array}{l}\text { Olumlu Görüş (Açıklama } \\
\text { Paragrafi) }\end{array}$} & Frekans & 30 & 0 & 30 \\
\hline & Yüzde & $\% 100$ & $\% 0$ & $\% 100$ \\
\hline \multirow{2}{*}{$\begin{array}{l}\text { Görüş } \quad \text { Bildirmekten } \\
\text { Kaçınma/Olumsuz }\end{array}$} & Frekans & 8 & 1 & 9 \\
\hline & Yüzde & $\% 89$ & $/ 11$ & $\% 100$ \\
\hline \multirow[b]{2}{*}{ Toplam } & Frekans & 155 & 196 & 351 \\
\hline & Yüzde & $\% 45$ & $\% 55$ & $\% 100$ \\
\hline
\end{tabular}

Tablo 2'ye göre sürekliliği ile ilgili belirsizlik olduğu yönünde tahminde bulunulan 155 finansal rapordan 30 tanesi için şartlı denetim görüşü, 8 tanesi için ise görüş bildirmekten kaçınma veya olumsuz görüş, 117 tanesi için olumlu denetim görüşü verilmiştir. Ancak olumlu görüşün verildiği 117 denetim raporunun 30 tanesinde süreklilik ile ilgili belirsizliği ifade etmek amacıyla açıklama paragrafı kullanılmıştır.

Çalışmanın daha önceki bölümlerinde de bahsedildiği üzere BDS 570'e göre; işletme yönetiminin finansal tabloları işletmenin sürekliliği varsayımına göre hazırladığını belirtmesi ancak denetçinin yargısının tam tersi yönünde olması durumunda denetçi şartlı görüş veya olumsuz görüş vermektedir. Bununla birlikte işletme yönetimi tarafından süreklilik ile ilgili belirsizlik konusunda yeterli açıklama yapılması durumunda ise denetçi olumlu görüş bildirerek söz konusu durumu açıklama parağrafı yardımıyla raporlayabilir (BDS 570, p. 21). Bunun dışında denetçi görüşünün türünü etkileyen tek husus işletmenin sürekliliği ile ilgili belirsizliğin var olması değildir. Bu nedenle çalışmanın bundan sonraki bölümlerinde denetim raporları ayrıntılı olarak incelenmiştir. Böylece hangi denetim raporlarında süreklilik ile ilgili belirsizliğe yer verildiği ortaya konulmaya çalışılmıştır. 
Tablo 3. Şartlı Görüş Bildirilen Denetim Raporları

\begin{tabular}{|c|c|c|c|c|}
\hline Modelin Tahmini & \multicolumn{2}{|c|}{ Süreklilik ile ilgili belirsizlik var } & \multicolumn{2}{|c|}{ Süreklilik ile ilgili belirsizlik yok } \\
\hline Denetçi Görüşü & 30 & & 24 & \\
\hline Şartlı Görüş & $\begin{array}{l}\text { Süreklilik ile } \\
\text { ilgili belirsizliğe } \\
\text { denetim } \\
\text { raporunda yer } \\
\text { verilmiş }\end{array}$ & 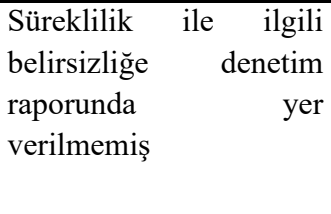 & $\begin{array}{l}\text { Süreklilik ile } \\
\text { ilgili belirsizliğe } \\
\text { denetim } \\
\text { raporunda yer } \\
\text { verilmiş }\end{array}$ & 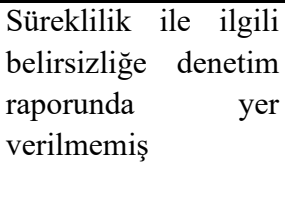 \\
\hline & 20 & 10 & 2 & 22 \\
\hline
\end{tabular}

Tablo 3'e göre, çalışma kapsamına alınan denetim raporlarının 54 tanesinde şartlı görüş bildirilmiştir. Bu raporlardan 22 tanesinde görüşün verilme gerekçesi sürekliliği ile ilgili belirsizliktir. Model ise, şartlı görüş alan 30 finansal raporda sürekliliği ile ilgili belirsizlik tahmini yapmıştır. Dolayısıyla 20 tane finansal rapor için modelin tahmini ile denetçi kanaati paralellik göstermektedir. Ancak 10 finansal raporda denetçi kanaati ile model tahmini eşleşmemektedir. Söz konusu 10 denetim raporu ve bu raporun hazırlandığ 1 işletmeler incelenmiştir. Buna göre, denetim raporlarının aynı iki işletme için hazırlandığı, denetim raporunu hazırlayan denetim firmasının da aynı olduğu görülmüştür.

Rotasyon, belirli bir denetim müşterisine, belirli bir süre denetim hizmeti verildikten sonra, oluşabilecek yakınlık tehdidini önlemek amacıyla belirli bir süre o müşterinin denetiminin üstlenilmemesi olarak ifade edilmektedir. 6102 sayılı Türk Ticaret Kanununun 400. Maddesi’ne göre, on yıl içinde aynı şirket için toplam yedi yıl denetçi olarak seçilen denetçi üç yıl geçmedikçe denetçi olarak yeniden seçilemez. Bununla birlikte, Bağımsız Denetim Yönetmeliğinin 26. Maddesine göre, üç yıl geçmedikçe, denetim kuruluşları son on yılda yedi yıl, denetim üstlenen bağımsız denetçiler ile bunların yanında ve denetim kuruluşlarında çalışan denetçiler ise son yedi yılda beş yıl denetim çalışması yürüttükleri işletmelere ilişkin denetimleri üstlenemezler (http://kgk.gov.tr). Çalışmanın sonuçları göstermektedir ki, Türkiye'de rotasyon uygulaması bulunmasına rağmen, halen aynı denetçi tarafından üst üste denetlenen raporların güvenilirliğinin diğer raporlara göre daha düşük olduğu düşünülmektedir. Çünkü çalışmada modelin kanaati ile denetçinin kanaati, süreklilik varsayımı doğrultusunda karşılaştırıldığında, çelişkinin sadece rotasyon nedeniyle denetim firmasını değiştiren, rotasyon süresi boyunca aynı denetim firması ile çalışmayı tercih eden işletmelerde ortaya çıktığı görülmektedir. 
Tablo 4. Olumlu Görüş Bildirilen Denetim Raporları

\begin{tabular}{|l|l|l|l|l|}
\hline Modelin tahmini & \multicolumn{2}{|l|}{ Süreklilik ile ilgili belirsizlik var } & \multicolumn{2}{|l|}{ Süreklilik ile ilgili belirsizlik yok } \\
\hline Denetçi Görüşü & \multicolumn{2}{|c|}{117} & \multicolumn{2}{|c|}{171} \\
\hline \multirow{3}{*}{ Olumlu Görüş } & $\begin{array}{l}\text { Süreklilik riskine } \\
\text { denetim raporunda } \\
\text { yer verilmiş }\end{array}$ & $\begin{array}{l}\text { Süreklilik riskine } \\
\text { denetim } \\
\text { raporunda yer } \\
\text { verilmemiş }\end{array}$ & $\begin{array}{l}\text { Süreklilik riskine } \\
\text { denetim raporunda } \\
\text { yer verilmiş }\end{array}$ & $\begin{array}{l}\text { Süreklilik riskine } \\
\text { denetim } \\
\text { raporunda yer } \\
\text { verilmemiş }\end{array}$ \\
\cline { 2 - 5 } & 30 & 87 & 0 & 171 \\
\hline
\end{tabular}

Tablo 4'de olumlu görüş bildirilen denetim raporları ayrıntılı olarak incelenmiştir. Model 117 işletmenin sürekliliği ile ilgili belirsizlik tahmini yapmış, denetçilerden 30 tanesi de açıklama parağrafı yardımıyla bu durumu raporlarında belirtmişlerdir. Ancak 87 işletme için model süreklilik ile ilgili belirsizlik tahmini yapmasına rağmen, denetçi bu yönde bir kanaat belirtmemiştir.

Çalışmanın daha önceki bölümünde bahsedildiği üzere, Bağımsız Denetim Standardı (BDS) 570, işletmelerin süreklilik göstergelerini; işletme faaliyetleri ile ilgili göstergeler, finansal göstergeler ve diğer konularla ilgili olmak üzere üç kategoriye ayırmıştır. Standart bu göstergelerin tek başına var olmasının her zaman işletmenin sürekliliği ile ilgili önemli bir belirsizliğin var olduğu anlamına gelmeyeceğini de belirtmiştir (BDS 570, A.3). Bununla birlikte finansal verilerine göre, borçlarını ödeme konusunda dar boğazda bir işletme varlık satışı yoluyla borçlarını kapatabilir. Bu nedenle finansal verileri açısından sürekliliği ile ilgili belirsizlik tahmin edilmesine rağmen denetçinin kanaatinin bu yönde olmamasının yukarıda bahsedilen bir sebepten kaynaklı olabileceği düşünülmektedir.

Tablo 5. Görüş Bildirmekten Kaçınma/Olumsuz Görüş Bildirilen Denetim Raporları

\begin{tabular}{|l|l|l|l|l|}
\hline Modelin Tahmini & \multicolumn{3}{|l|}{ Süreklilik Ile ilgili belirsizlik var } & \multicolumn{2}{l|}{ Süreklilik Ile ilgili belirsizlik yok } \\
\hline Denetçi Görüşü & 8 & 18 & \multicolumn{2}{|l|}{} \\
\hline $\begin{array}{l}\text { Görüş Bildirmekten } \\
\text { Kaçınma/Olumsuz } \\
\text { Görüş }\end{array}$ & $\begin{array}{l}\text { Süreklilik riskine } \\
\text { denetim raporunda } \\
\text { yer verilmiş }\end{array}$ & $\begin{array}{l}\text { Süreklilik riskine } \\
\text { denetim raporunda } \\
\text { yer verilmemiş }\end{array}$ & $\begin{array}{l}\text { Süreklilik } \\
\text { riskine denetim } \\
\text { raporunda yer } \\
\text { verilmiş }\end{array}$ & $\begin{array}{l}\text { Süreklilik riskine } \\
\text { denetim raporunda } \\
\text { yer verilmemiş }\end{array}$ \\
\cline { 2 - 5 } & 8 & 0 & 1 & 17 \\
\hline
\end{tabular}

Tablo 5'de görüldüğü üzere model tarafından, olumsuz görüş alan 26 finansal rapordan 8 'inde süreklilik ile ilgili belirsizlik tahmini yapılırken, denetçinin kanaatinin de bu yönde olduğu görülmüştür. Bununla birlikte diğer 18 işletme için modelin sonuçlarına göre sürekliği ile ilgili bir belirsizlik söz konusu değilken denetçinin de aynı kanaatte olduğu görülmektedir. Bu raporlar incelendiğinde olumsuz görüş bildirme gerekçesinin süreklilik ile ilgili belirsizlik olmadığı anlaşılmıştır. 


\section{Sonuç}

Yaşanan finansal krizler ile birlikte piyasalarda iflas eden işletme sayısında yaşanan artış ülkelerin ekonomisine ciddi zararlar vermeye başlamıştır. Bu durum işletmelerin sürekliliği ile ilgili tartışmaları da beraberinde getirmiştir. Hem muhasebe ve finansal raporlama standartlarında hem de denetim standartlarında işletmenin sürekliliğine özellikle vurgu yapılmaktadır. Söz konusu standartlar süreklilik ile ilgili hem işletme yönetimine hem de bağımsız denetçiye ciddi sorumluluklar yüklemektedir. Bu kapsamda çalışmada, öncelikle Borsa İstanbul'da imalat sektöründe işlem gören işletmelerin 2009 ve 2017 yılları arasında yayınladıkları finansal raporlar kullanılarak Altman'ın Z Skoru yardımıyla süreklilikleri ile ilgili belirsizlik tahmini yapılmıştır. Daha sonrasında modelin sonuçları ile çalışma kapsamına alınan finansal raporlar için verilmiş denetim raporları ve bu raporlarda bildirilen denetçi görüşleri karşılaştırılmıştır.

Çalışmada denetçi tarafından verilen görüşler ile modelin yapmış olduğu tahmin arasında anlamlı bir ilişki bulunmuştur. Buna göre, modelin belirsizlik tahmini yaptığı finansal raporların çoğunluğunda denetçiler de aynı kanaattedir. Söz konusu durumda çoğunlukla şartlı görüş veya olumlu görüş (açıklama parağrafı ) verilmiştir. Bununla birlikte bazı tahmin sonuçları ile denetçi kanaati paralellik göstermemektedir. Örneğin model süreklilik ile ilgili belirsizlik tahmini yapmasına rağmen, denetçi şartlı görüş bildirmiş ancak süreklilik ile ilgili belirsizliğe raporda yer vermemiştir. Bu durum rotasyon süresi boyunca denetim firmasını hiç değiştirmeyen ve aynı denetim firmaları tarafından denetlenen iki işletmenin finansal raporlarında ortaya çıkmıştır. Dolayısıyla bu sonuç rotasyon süreleri ile ilgili soru işaretleri oluşmasına neden olmuştur. Çalışma kapsamına alınan bazı finansal raporlar için model süreklilik ile ilgili belirsizlik tahmini yapmasına rağmen denetçinin olumlu rapor verdiği ve söz konusu duruma raporunda yer vermediği görülmüştür. Bu alanda bundan sonra yapılacak çalışmalarda işletmelerin süreklilikleri ile ilgili belirsizliğin tahmin edilmesinde finansal verilerin yanında diğer işletme verilerini de kullanan bir model kullanılabilir. Ayrıca model yardımıyla süreklilik ile ilgili belirsizlik tahmini yapıldıktan sonra, işletmenin bu durumu ortadan kaldırmak için bir planı hayata geçirip geçirmediği de incelenebilir.

\section{Kaynakça}

Altman, E. I. (1968). Financial Ratios, Disciriminant Analysis and The Prediction of Corporate Backrupty, The Journal of Finance, XXII( 4). doi :10.2307/2978933

Attilla, S.T. vd. (2012). The Principle of Business Continuity in Terms of Financial Audit, Annales Universitatis Apulensis Series Oeconomica, 14(2). http://www.oeconomica.uab.ro/upload/lucrari/1420122/13.pdf.

Eymen, E. (2007). SPSS 15.0 Veri Analiz Yöntemleri, No:1, Ankara: İstatistik Merkezi. 
Kamu Gözetim Kurumu (KGK), Bağımsız Denetim Standardı 570: İşletmenin Sürekliliği, www.kgk.gov.tr (Erişim Tarihi: 24.04.2019).

Kamu Gözetim Kurumu (KGK), Türkiye Muhasebe Standardı 1: Finansal Tabloların Sunuluşu, www.kgk.gov.tr (Erişim Tarihi: 24.04.2019).

Kamu Gözetim Kurumu (2019). Bir denetim Faaliyetinin üstlenilmesinde dikkat etmem gereken rotasyon sürelerine ilişkin düzenlemeler nelerdir, www.kgk.gov.tr (Erişim Tarihi: 17.09.2019).

Kalaycı, Ş. (2005). SPSS Uygulamalı Çok Değişkenli İstatistik Teknikler, 1. Baskı, Ankara: Alfa.

Kulalı, İ. (2016). Altman Z-Skor Modelinin BİST Şirketlerinin Finansal Başarısızlık Riskinin Tahmin Edilmesinde Uygulanması, Uluslararası Yönetim İktisat ve İşletme Dergisi, 12 (27), 283-291, doi: 1017130/ijmeb.2016.12.27.1076.

Provasi, R., Riva, R. ( 2015). Assessment of Going Concern For The Italian Listed Companies: An Empirical Study. Review of Business and Finance Studies, 6(1)., 27-34, https://papers.ssrn.com/sol3/papers.cfm?abstract_id=2497042.

Selimoğlu Kardeş, S., Uzay, Ş., (2008). Muhasebe Denetimi, Ankara: Gazi.

Stanisic, N. Radojevic, T., Stanic N. ve Rajin, D. (2013). The Association between Auditor Switching and Audit Opinion in The Republic of Serbia, Finiz Conference, Belgrade, 552-558, doi: 10.15308/sinteza2014.

Tanç, Ş. (2010). Bağımsız Denetim Karar Sürecinde İşletmenin Sürekliliği: Türkiye’deki Bă̆ımsız Denetime Tabi İşletmeler Üzerine Bir Araştırma. (Yayınlanmamış Doktora Tezi). Erciyes Üniversitesi/ Sosyal Bilimler Enstitüsü, Kayseri.

Terzi, S., Atmaca, M. ve Öktem, B. (2016). İşletmenin Sürekliliği Varsayımının Değerlendirilmesi: Borsa İstanbul (BİST) Sınai Endeksi Örneği, Marmara Üniversitesi Öneri Dergisi, 1 (45), Ocak 2016, 515-535, doi: 10.14783/od.V12i45.1000020024.

Triani, N, Satyawan, M. D. ve Yanthi, M. D. (2017). Determining the Effectiveness of Going Concern Audit Opinion by ISA 570. Asian Journal of Accounting Research, 2, 29-35, doi: 10.1108/ AJAR-2017-02-02-B004. 
Turaboğlu, T.T., Erkol Yıkmaz, A. ve Topaloğlu, E. E. (2017). Finansal Başarısızlık ve Sermaye Yapısı Kararları: BİST 100 Endeksindeki Firmalar Üzerine Bir Uygulama, Business and Economics Research Journal, 8(2), 247-258, doi: 10.20409/berj.2017.48.

Uzay, Ş. (2017). Sürdürülebilir Gelişme Bakımından Denetimin Önemi. Muhasebe ve Denetim Sempozyumu, 27-28 Eylül 2017, İstanbul.

Yıldız, F. O. (2017). İşletmelerde Borca Batıklık ve Süreklilik Denetimi, İstanbul: Maliye Hesap Uzmanları Derneği.

Yılmaz, Z., Yaşar, A. (2018). Bağımsız Denetim Raporlarının İşletmenin Sürekliliği Denetim Standardı 570 Çerçevesinde İncelenmesi: BİST İmalat Sanayi Şirketleri Üzerine Bir Araştırma, Mali Çözüm Dergisi, Ocak-Şubat 2018, 55-90, https://issuu.com/istanbulsmmmodasi/docs/145. 